\title{
Part II Moments
}

\begin{abstract}
This section consists of three chapters. Each chapter includes two to four individual case studies drawn from the empirical data collected in the Moments project. The case studies are categorized around three main themes that emerged from the collected moments, Relationships, Change, and Death. In a unique moment to moment format, the author responds to each selected moment using interpretive methods usually limited to literary texts. The source of the interpretation ranges across the social and physical sciences and humanities, including the work of Paul Ricouer, John Bowlby, Martin Buber, Brian Massumi, Roland Barthes, and Luce Irigary.
\end{abstract}

Forrest, Kelly. Moments, Attachment and Formations of Selfhood: Dancing with Now. Basingstoke: Palgrave Macmillan, 2013. DOI: 10.1057/9781137300577. 